Article

\title{
The Effect of Light Intensity on Vegetative Propagation Efficacy, Growth, and Morphology of "Albion" Strawberry Plants in a Precision Indoor Propagation System
}

\author{
Xiangnan Xu and Ricardo Hernández * \\ Department of Horticultural Science, North Carolina State University, Raleigh, NC 27695, USA; xxu25@ncsu.edu \\ * Correspondence: ricardo_hernandez@ncsu.edu
}

Received: 12 December 2019; Accepted: 24 January 2020; Published: 4 February 2020

\begin{abstract}
Open-field strawberry propagation is faced with several challenges such as lack of daughter plants, low quality, and disease transmission. Propagating strawberry plants in a completely enclosed controlled environment using a precision indoor propagation (PIP) system could overcome some of the challenges seen in open-field strawberry propagation. Optimizing the light intensity in a PIP system improves plant growth and reduce propagation cost. In the present study, "Albion" strawberry plants were grown as stock plants in a PIP system to examine plant propagation efficacy under three light intensities, PPF-250 (241 \pm 13), PPF-350 (337 \pm 13$)$, or PPF-450 (443 \pm 17$)$ photosynthetic photon flux density (PPFD, $\mu \mathrm{mol} \mathrm{m} \mathrm{m}^{-2} \mathrm{~s}^{-1}$ ) at $12 \mathrm{~h}$ photoperiod. They were grown under $25.7 \pm 0.05{ }^{\circ} \mathrm{C}$ temperature, $0.95 \pm 0.04 \mathrm{kPa}$ vapor pressure deficit, and $73 \% \pm 5.2 \%$ relative humidity. The number of daughter plants, morphology, and growth were recorded weekly (non-destructive measurements) for two intervals ( 01 to 12 weeks and 12 to 21 weeks). The number, total dry mass, and total fresh mass of daughter plants per stock plant increased with the increase in light intensity. The propagation efficacy to light ranged between 0.3 and 1.9 daughter plants per mole of light, depending on light intensity and harvest time. The number of daughter plants per week was estimated to be 36.2 plants $\mathrm{wk}^{-1} \mathrm{~m}^{-2}$. Daughter plants were classified by size and size was not influenced by the light treatment. Stock plant crown diameter, leaf area, fresh mass, dry mass, and leaf count all increased with an increase in PPFD. The shoot dry mass percent distribution to the daughter plant was $45 \%$ to $46 \%$ and was not affected by light intensity treatment. This study demonstrates the feasibility of using PIP systems for the production of strawberry daughter plants.
\end{abstract}

Keywords: day-neutral strawberry; light intensity; daily light integral; precision indoor propagation; daughter plant production

\section{Introduction}

The large strawberry production industry in the USA is composed of approximately 52,700 acres [1] at an approximate density of 21,780 plants per acre [2]. Since the propagation of strawberries is mainly vegetative, the USA industry requires a vast number of cloned plants, such as bare roots and plugs, to meet the geographical and seasonal demand. In order to have enough planting material (daughter plants) to supply fruit growers, propagators have to carefully coordinate the reproduction of strawberry stock plants for several years and in multiple geographical locations (USA and Canada). The current field propagation system is vulnerable to several problems including a decrease in plant quality after long storage, low availability of planting material, and high risk of pathogen transmission from the nursery to the production field. For example, anthracnose has been identified as a typical nursery 
transmitted disease that remains symptomless during propagation; however, devastating symptoms appear late in the fruit production season [3].

"Albion" strawberry plants became popular in Southeastern United States for extended season production. Albion is commonly classified as a "day-neutral" (everbearing) flowering plant since it is capable of flowering under both long-day and short-day light conditions [4]. Recent research has shown that Albion shows a facultative long-day response where flowers initiate faster under long-day condition [4]. Albion and other day-neutral cultivars often produce low numbers of daughter plants in open-field propagation systems [5].

Asexually propagating strawberry plants in a controlled environment using precise environmental strategies (precision indoor propagation, PIP) could address some of the challenges of open-field strawberry propagation. For example, environmental conditions can be controlled to initiate or prevent plant flowering [6], improve plant morphology (compactness and extension) [7], and maintain higher consistency of plant quality (uniformity) [8], among others. In addition, PIP systems have higher protection from the inoculum of outside pest or pathogens. Research has demonstrated the potential of indoor systems to propagate several crops including snapdragon [9], petunia, impatiens, salvia [10], tomato [10,11], cabbage [12], grape [13], cucumber [14,15], and stevia [16], among others.

One of the main challenges for the adoption of indoor growing systems such as PIP is the high energy demand driven by the use of electrical lighting for photosynthesis. Therefore, research studies in other crops have focused on optimizing the use of light in indoor production systems, for example, adjusting the photoperiod for leafy green production [17] and increasing $\mathrm{CO}_{2}$ concentration to increase photosynthesis under lower light intensity [18]. In order to make PIP systems more affordable for the propagation of strawberries, it is imperative to find the optimal light intensity to increase the number of daughter plants produced and to decrease energy consumption.

Few studies have focused on light intensity for strawberry propagation. In one study, "Toyonok" (short-day) strawberry plants were grown for stolon production under different light sources and spectrums [19]. Results showed that 110 to $122 \mu \mathrm{mol} \mathrm{m}^{-2} \mathrm{~s}^{-1}$ photosynthetic photon flux density (PPFD) provided by white fluorescent lamps (5000 and $6500 \mathrm{~K}$ color temperature) promoted both stock-plant growth and formation of daughter plants as compared with plants under 50 to $55 \mu \mathrm{mol} \mathrm{m} \mathrm{m}^{-2} \mathrm{~s}^{-1}$ provided by fluorescent lamps with warmer color temperature (4000 and $3000 \mathrm{~K}$ ) [19].

Light emitting diodes (LEDs) of different colors have been examined as the light source for strawberry propagation. For example, plants in 30\% blue/70\% red photon flux density (30B:70R) treatment produced the highest total number of stolons, whereas, in $20 \%$ blue $/ 10 \%$ green $/ 70 \%$ red (20B:10G:70R) treatment, plants had the highest daughter plants per stolon [20]. "Maehyang" (short-day) strawberry plants produced a significantly greater number of daughter plants under $280 \mu \mathrm{mol} \mathrm{m}{ }^{-2} \mathrm{~s}^{-1}$ photosynthetic photon flux density (PPFD) as compared with $140 \mu \mathrm{mol} \mathrm{m} \mathrm{m}^{-2} \mathrm{~s}^{-1}$ and $220 \mu \mathrm{mol} \mathrm{m} \mathrm{m}^{-2} \mathrm{~s}^{-1}$ (photoperiod $16 \mathrm{~h}$ ) with a daily productivity of 0.27 daughter plants per stock plant [20]. However, these reports only focused on relatively low PPFD treatments (50 to $280 \mu \mathrm{mol} \mathrm{m}{ }^{-2} \mathrm{~s}^{-1}$ ) and short-day strawberry cultivars.

Typical plant responses to light intensity follow the logarithmic curve in which increases in photosynthesis are greater at the beginning but gains decrease over time until a saturation point is achieved [21]. At light saturation point, photosynthesis no longer increases with increases in light intensity since photosynthesis is Calvin cycle limited [21]. Different crops have different light saturation points. For strawberry plants, the saturation point for photosynthetic rate has been reported to be at PPFD of 400 to $600 \mu \mathrm{mol} \mathrm{m}{ }^{-2} \mathrm{~s}^{-1}$ [22,23]. However, a maximum photosynthetic rate does not always lead to an increase of yield since photoassimilates can be translocated to parts of the plant that are not part of the harvest index, such as leaves, crown, roots, etc. The objective of the present study is to evaluate the effect of light intensity ( 250 to $450 \mu \mathrm{mol} \mathrm{m}^{-2} \mathrm{~s}^{-1}$ ) specifically for the production of daughter plants on day-neutral strawberry plants. 


\section{Materials and Methods}

\subsection{Material Preparation}

On 16 October, 2017 one thousand "Albion" strawberry daughter plants obtained from Cottle Farm Inc. (Faison, CA, USA) were planted into 50-cell trays (96 mL) filled with C/P growing mix (Jolly Gardener Pro-Line, Poland Spring, ME, USA) and placed in a greenhouse under mist to promote rooting (temperature set to $21^{\circ} \mathrm{C}$ ). Rooting daughter plants received controlled mist for 42 days with a frequency of $1 \mathrm{~min}$ for every $5 \mathrm{~min}$ ( 1 to 7 days), then $3 \mathrm{~min}$ per hour (7 to 14 days), and 10 min per day for the last 21 days.

In order to move the plant material into a clean growth chamber on (2 February 2018), leaves and substrate were removed from 90 plug plants with similar crown diameter. Plants were dipped in miticide (Mavrik Aquaflow, Central Life Sciences, Schaumburg, IL, USA) and temporarily transplanted into small individual pots $(240 \mathrm{~mL})$ and placed in a growth chamber with $75 \%$ relative humidity, 22/18 ${ }^{\circ} \mathrm{C}$ (day/night) temperature, and $250 \mu \mathrm{mol} \mathrm{m} \mathrm{m}^{-2} \mathrm{~s}^{-1}$ PPFD (12 $\mathrm{h}$ photoperiod) for foliage regeneration. On 17 February 2018, 45 plug plants with two expanded leaves and similar crown diameter $(7.29 \pm 0.75 \mathrm{~mm})$ were selected for the experiment and transplanted into $3.8 \mathrm{~L}$ pots (1 gallon pot) with a substrate mixture composed of $50 \%$ perlite, $25 \%$ coconut coir, and $25 \%$ of peat moss.

\subsection{Environmental Control and Growing Conditions}

Plants were grown in a growth chamber $\left(8.6 \mathrm{~m}^{2}\right)$ inside a Phytotron research facility at North Carolina State University (Raleigh, CA, USA). Temperature, relative humidity (SHT75, Sensirion, Laubisruetistrasse 50, 8712 Staefa ZH, CH) and carbon dioxide (Vaisala CARBOCAP, Vaisala, FI-00421 Helsinki, Finland) sensors were deployed in an aspirated box inside the chamber. In addition, nine fine-wire thermocouples (type T, gauge 24, Omega Inc., Stamford, CA, USA) were deployed (one per treatment and replication) to measure canopy temperature. All environmental data was recorded every three minutes (aspirated box) and every minute (thermocouples) using a datalogger (CR1000, Campbell Scientific, Logan, UT, USA). Environmental parameters are reported for two experimental periods, weeks 01 to 12 and 12 to 21 , each with three replications as shown in Table 1 . The temperature used in this experiment $\left(26^{\circ} \mathrm{C}\right.$, Table 1$)$ was greater than the recommended growing temperature for strawberry fruit production of 18 to $21^{\circ} \mathrm{C}$ [24-26] since it has been reported that warmer temperatures increase stolon and daughter plant growth [24,27].

Table 1. Light intensity treatments and environmental parameters measured inside the growth chamber. Average and standard deviations of the three repetitions for two growing cycles (week 01 to 12 and 12 to 21 weeks).

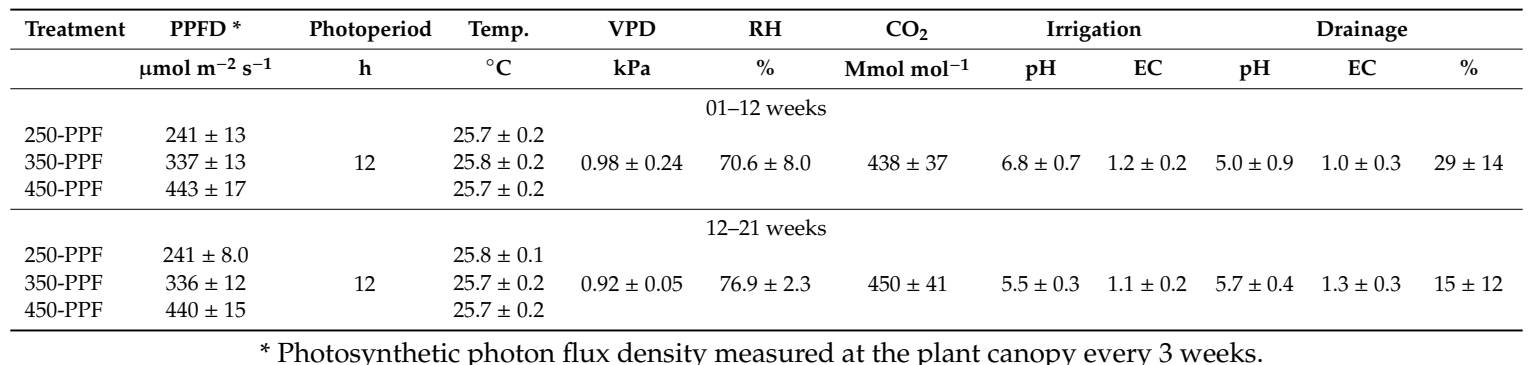


Plants were subjected to three different light intensity treatments measured with a quantum sensor (LI 1500 Sensor Logger and LI 190R Quantum Sensor, LI-COR, Lincoln, NE, USA) as follows: (1) 250-PPF (241 \pm 13), (2) 350-PPF (337 \pm 13$)$, and (3) 450-PPF (443 \pm 17$)$ photosynthetic photon flux density $\left(\mu \mathrm{mol} \mathrm{m} \mathrm{m}^{-2} \mathrm{~s}^{-1}\right.$ ) provided by cool white fluorescent lamps (4100 K) (Table 2, Figure 1). Plants were grown under a short-day photoperiod of $12 \mathrm{~h}$ to reduce flowering since recent reports showed that "Albion" initiates flowers faster under long-day conditions [4]. Horticultural shade cloth (Harmony 4647FR, Harmony 3315FR, and Luxous 1347; Ludvig Svensson, Inc., Charlotte, NC, USA) was used to adjust the light intensity under each treatment. In addition, the shade cloth was adjusted every three weeks to ensure that photon flux density at the canopy level was within $10 \%$ of the initial intensity. The nutrient recipe used included $\left(\mathrm{mg} \mathrm{L}^{-1}\right) 80 \mathrm{NO}_{3}-\mathrm{N}, 20 \mathrm{NH}_{4}-\mathrm{N}, 21.4 \mathrm{P}, 145.2 \mathrm{~K}$, $60 \mathrm{Ca}, 12.2 \mathrm{Mg}$, and $39 \mathrm{~S}$, as well as micronutrients. The nutrient solution was delivered using a drip-irrigation system controlled by three soil moisture sensors $\left(\mathrm{ECH}_{2} \mathrm{O}\right.$ EC-5, METER Environment, Pullman, WA, USA). Before the start of the experiment, sensors were calibrated to trigger irrigation when the substrate reached 35\% volumetric water content. During the experiment, the amount of irrigation was adjusted by increasing the irrigation time ( $\mathrm{min}$ ) of the emitters (rate, $100 \mathrm{~mL} \mathrm{~min}{ }^{-1}$ ) to maintain a drainage of $15 \%$ to $30 \%$. Electrical conductivity and $\mathrm{pH}$ were measured daily for both irrigation water and drainage water. Percent drainage was also measured every day (Table 1).

Table 2. Average light quality composition for the three light intensity treatments under fluorescent (4100 K) fixtures, the percent photon flux density (PFD) is presented for ultraviolet (UV), blue (B), green $(\mathrm{G})$, red (R), and far-red (FR), on $100 \mathrm{~nm}$ increments.

\begin{tabular}{cccccc}
\hline Wavelength (nm) & $\mathbf{3 0 0 - 4 0 0}$ & $\mathbf{4 0 0 - 5 0 0}$ & $\mathbf{5 0 0 - 6 0 0}$ & $\mathbf{6 0 0 - 7 0 0}$ & $\mathbf{7 0 0 - 8 0 0}$ \\
\hline & UV (\%) & B (\%) & G (\%) & R (\%) & FR (\%) \\
PFD & $0.51 \pm 0.18$ & $17.9 \pm 0.86$ & $41.1 \pm 0.42$ & $35.6 \pm 0.44$ & $4.7 \pm 0.64$ \\
\hline
\end{tabular}

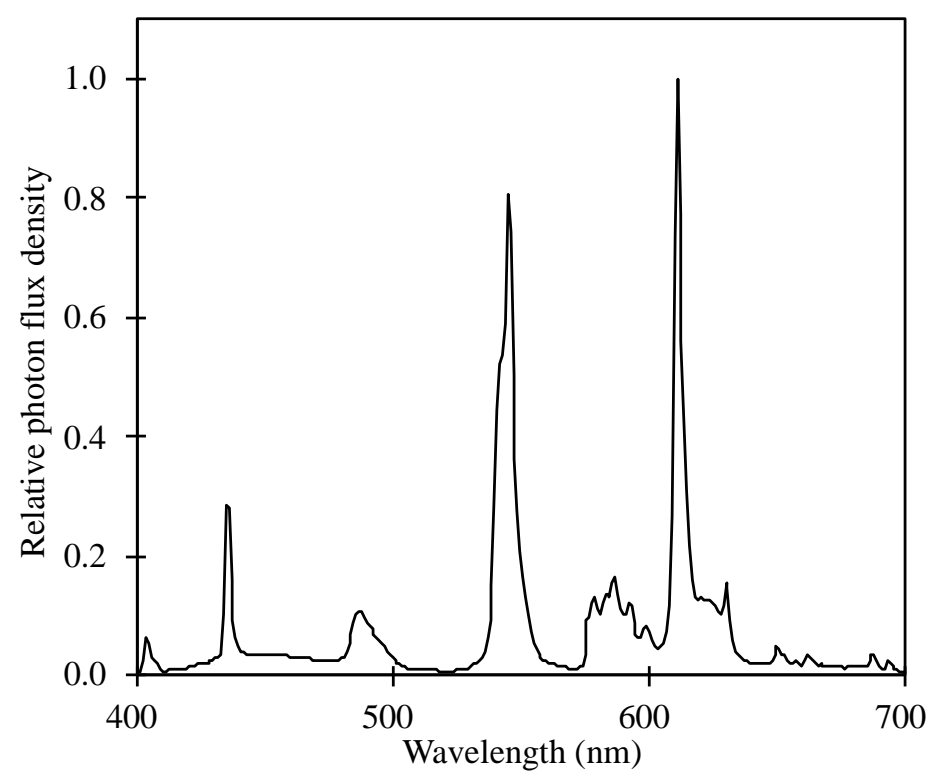

Figure 1. Photosynthetic active radiation $(400$ to $700 \mathrm{~nm})$ spectral distribution graph for cool white fluorescent $(4100 \mathrm{~K})$ used for the three light intensity treatments. Spectral distribution was normalized with $\max 1.0$.

\subsection{Experimental Design and Data Collection}

Nine growing zones were created in the growth chamber with three zones assigned randomly to each of the three light treatments ( 3 treatments, 3 replications). Forty-five potted plants were randomly placed into nine zones (five plants each). 
Every week, crown diameter, number of leaves, stolons, and daughter plants were recorded for each stock plant. After 12 weeks (9 weeks of daughter plant production period), all stolons were cut from the base. Daughter plants were excised from the stolons; and fresh mass (electronic scale), crown diameter (electronic caliper), leaf count (leaves greater than $1 \mathrm{~cm}$ ), leaf area (LI-3100 Area Meter, LI-COR Inc., Lincoln, NE, USA), and dry mass (electronic scale after dried for $72 \mathrm{~h}$ at $65^{\circ} \mathrm{C}$ ) were measured. Daughter plants were grouped into six categories based on the crown diameter size $(\mathrm{mm})$ (Figure 2) as follows: extra-large (XL) greater than 11, large (L) 8.5 to 11, medium (M) 6 to 8.5, small (S) 3.5 to $6 \mathrm{~mm}$, extra-small (XS) smaller than 3.5, and premature (PM) daughter plant buds (Figure 2). In addition, dry mass was measured on each stolon without daughter plants. This first cycle was from week 1 to 12 (01 to 12 weeks) in this experiment.

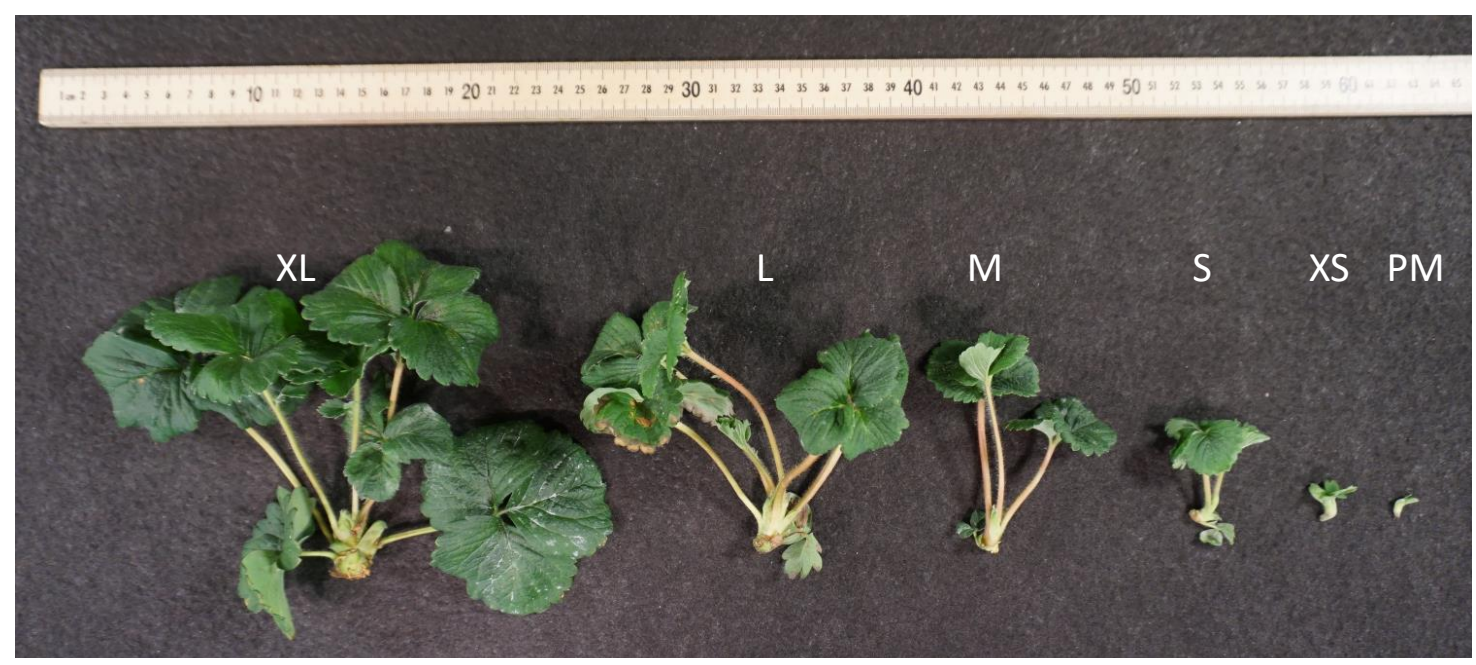

Figure 2. Daughter plant classifications based on crown diameter: Extra-large (XL) crown diameter greater than $11 \mathrm{~mm}$; large (L) crown diameter $8.5 \mathrm{~mm}$ to $11 \mathrm{~mm}$; medium $(\mathbf{M})$ crown diameter $6 \mathrm{~mm}$ to $8.5 \mathrm{~mm}$; small (S) crown diameter $3.5 \mathrm{~mm}$ to $6 \mathrm{~mm}$; extra small (XS) crown diameter smaller than $3.5 \mathrm{~mm}$; and premature buds (PM).

After removal of all stolons, the stock plants were returned to the growth chamber. The same parameters were measured for another 9 weeks (week 12 to 21 ). For weeks 12 to 21 , all the measurements were the same as described above for weeks 01 to 12 . In addition, at the end of week 21, stock plants were cut at the substrate level to quantify shoot fresh mass, leaf area, crown diameter, leaf count $(>1 \mathrm{~cm})$, and dry mass.

All data were analyzed using JMP software (SAS Institute, Cary, NC, USA). Linear regression was used to model the plant response to light intensity and growing time. To identify the difference among treatments, significance level $p=0.05$ was used. Tukey-Kramer HSD $(p=0.05)$ was used when analyzed mean separation. No interactions were found between treatment and repetition in any of the growing cycles (weeks 01 to 12 and 12 to 21 ).

\subsection{Crop Specific Efficacy to Light Calculations}

To compare the efficacy of light for the propagation of strawberry (number of daughter plants per mole of light), the calculations and estimations, described next, were made adopted after Kubota et al. [28].

\subsubsection{Propagation Efficacy of Strawberry Plants}

Crop specific efficacy to cumulative PPFD (grams of yield per mol of PPFD, $\mathrm{g} \mathrm{mol}^{-1}$ ) is described with a linear equation of the relationship between cumulative PPFD $\left(\mathrm{mol} \mathrm{m}^{-2}\right)$ and cumulative yield $\left(\mathrm{g} \mathrm{m}^{-2}\right)$ for the length of the production time. The slope of the linear equation can be used as a good 
estimation for crop specific efficacy to PPFD $\left(\mathrm{g} \mathrm{mol}^{-1}\right)$. This method has been used to estimate yield responses to light of crops such as tomato, strawberry, and lettuce [28-30]. For this experiment, a linear equation was fitted to the relationship of total amount of light (cumulative PPFD per meter square) and total amount of daughter plants (cumulative yield per meter square, 5.4 plants $\mathrm{m}^{-2}$ ) for the three light intensity treatments and the two growing cycles. The slope for the linear equation is a good estimation of the number of daughter plants per mol of light.

\subsubsection{Estimation of Number of Fixtures for Commercial PIP}

In order to estimate the electricity usage, the number of lamps required to provide the desirable PPFD at the growing area was estimated following Aldrich and Bartock [31]:

$$
N=\frac{P P F D \times A}{L P E \times E \times U F \times M F}
$$

where $N$ is the number of lamps required to irradiate a desired area, $A$ is the desired area $\left(A\right.$ of $1 \mathrm{~m}^{2}$ for ease of calculation), PPFD is the desired light intensity (PPFD 250, 350, or $450 \mu \mathrm{mol} \mathrm{m}^{-2} \mathrm{~s}^{-1}$ for this experiment), $L P E$ is the specific fixture efficacy in terms of number of photons per second per watt hour, and $\mathrm{E}$ is the fixture power consumption in Watts (LPE $3.0 \mu \mathrm{mol} \mathrm{m} \mathrm{m}^{-2} \mathrm{~W}^{-1}$ and $\mathrm{E} 600 \mathrm{~W}$ was used based on latest LED technology [32]), UF is defined as the utilization factor and it is based on fixture beam angle and geometry/reflectivity of the growing system, $U F=1$ is when all photons are captured by the plants (for this calculation, UF of 0.9 was used), $M F$ is defined as maintenance factor and considers the decay of light output over time, and $M F=1$ assumes no decay of light output by the fixture over time. MF of 0.9 was used for this calculation (assuming a 10\% light output decay over the fixture life) [28].

\subsubsection{Aerial Power Consumption and Electricity Cost per Mole of Light}

Using $N$ and $E$, the aerial power consumption $\left(A P C, \mathrm{~W} \mathrm{~m}^{-2}\right)$ was calculated following Hernández and Kubota [33]:

$$
A P C=N \times E
$$

We can then use the aerial power consumption to calculate the cost of electricity per mole of light $\left(\$ \mathrm{~mol}^{-1}\right)$ :

$$
\text { Electricity cost per mole of light }=A P C \times h \times E R
$$

where $A P C$ is the aerial power consumption in $\mathrm{kWh} \mathrm{m}^{-2}, h$ is the number of hours to reach one mole of photons at the different light intensities $\left(1.11,0.79\right.$, and $0.61 \mathrm{~h}$ for 250,350 , and $450 \mu \mathrm{mol} \mathrm{m}{ }^{-2} \mathrm{~s}^{-1}$, respectively), and $E R$ is the average USA electricity rate of $\$ 0.09 \mathrm{kWh}^{-1}$ [34].

\subsubsection{Electricity Cost per Daughter Plant}

The electricity cost per daughter plant (\$/daughter plant) is calculated by:

$$
\text { Electricity cost per daughter plant }=\frac{\text { Electricity cost per mole of light }}{\text { Propagation ef ficacy of strawberry }}
$$

where the propagation efficacy is obtained from Section 2.4.1 and the electricity cost per mole of light is calculated from Section 2.4.3. 


\section{Results and Discussion}

\subsection{Daughter Plants and Stolons}

The total number of daughter plants harvested per stock plant increased with an increase of light intensity (Figure 3). For the 01 to 12 week cycle, the total number of daughter plants in 250-PPF, 350-PPF, and 450-PPF was (mean \pm SD) $38.7 \pm 5.4,45.7 \pm 8.7$, and $56.7 \pm 8.5$, respectively. For the 12 to 21 week cycle, the total number of daughter plants for 250-PPF, 350-PPF, and 450-PPF was 41.9 $\pm 7.7,47.2 \pm 10$, and $50.6 \pm 8.2$, respectively. On a 21 week propagation cycle, the maximum production (460-PPF) was $\sim 107$ daughter plants per mother plant. To the best of our knowledge, this is the first study presenting the potential propagation yield in PIP systems for day-neutral strawberry plants. Other studies have shown the potential of controlled environment systems (greenhouses) to propagate strawberry plants, but studies have focused on short-day strawberry plants $[35,36]$. Short-day strawberry plants are known to be high producers of daughter plants. For example, short-day "Oso Grande" and "Sweet Charlie" mother plants produced 84 and 80 daughter plants per stock plant in 16 weeks under a greenhouse production system [35].

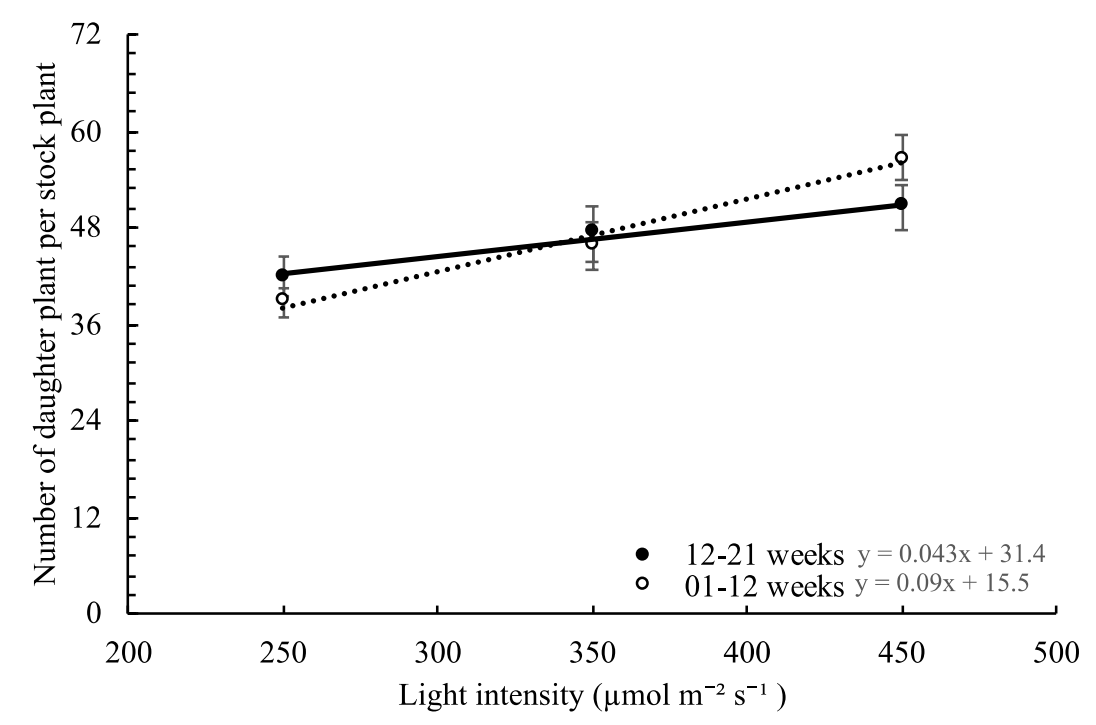

Figure 3. Effect of light intensity (mean \pm standard error) on the total number of daughter plants per stock plant of day neutral strawberry "Albion". Open circles ( $\bigcirc)$ represent data collected for 01 to 12 weeks and filled circles $(\bullet)$ represent data collected for 12 to 21 weeks. Dotted or solid lines represent significant linear regression $(p \leq 0.05)$.

The effect of light intensity on total dry mass, total fresh mass, and total leaf area of all daughter plants harvested after each growing cycle is shown in Figure $4 a-c$, respectively. For the 01 to 12 week cycle, the total dry mass and fresh mass of all daughter plants harvested per stock plant increased with an increase of light intensity. For the 12 to 21 week cycle, the increase was less evident, but the trend was still present $(p=0.070$ and $p=0.068)$. The total leaf area of all daughter plants per stock plant increased with an increase of light intensity for the 01 to 12 week cycle but did not increase for the 12 to 21 week cycle. 

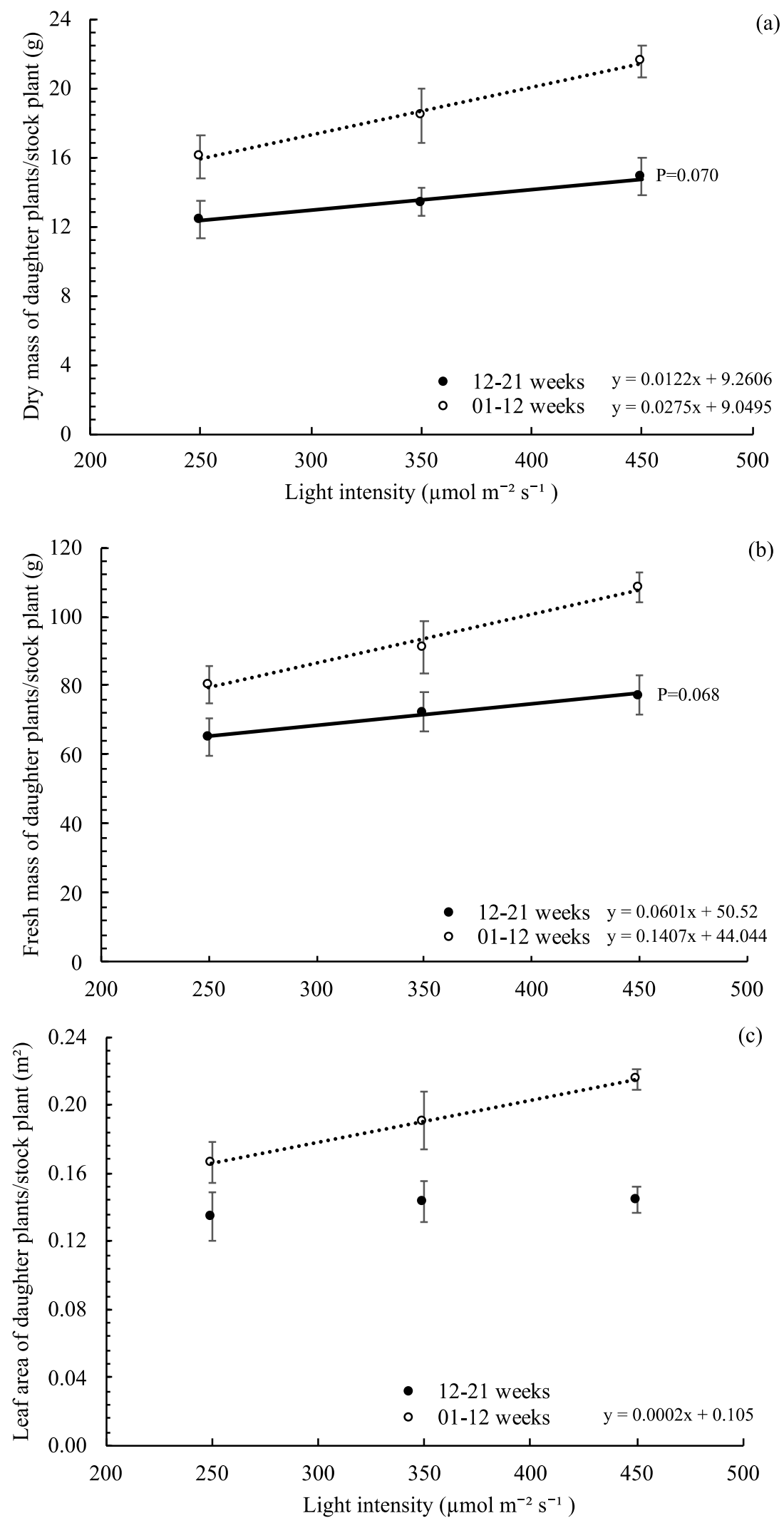

Figure 4. (a) Effect of light intensity on the total dry mass; (b) total fresh mass; (c) total leaf area, of all daughter plants harvested after each cycle per stock plant of day neutral strawberry "Albion". Open circles $(\bigcirc)$ represent data collected when stock plant was 12 weeks old and filled circles $(\bullet)$ represent data collected when stock plant was 21 weeks old. Dotted or solid line represents significant linear regression with $p \leq 0.05$. 
Plants under the $450-\mathrm{PPF}$ treatment produced $34.1 \%$ and $19.7 \%$ greater daughter plant dry mass and $44.7 \%$ and $20.8 \%$ greater number of daughter plants in the 01 to 12 week cycle and 12 to 21 week cycle, respectively, as compared with plants under the 250-PPF treatment. This result is expected since higher daily light integral (DLI, $\mathrm{mol} \mathrm{m}^{-2} \mathrm{~d}^{-1}$ ) is associated with higher yield. In general, a $1 \%$ increase of light increases yield by $0.25 \%$ to $1.5 \%$ [37].

Research has shown the crop specific efficacy to cumulative PPFD (grams of yield per mol of PPFD, $\mathrm{g} \mathrm{mol}^{-1}$ ) of several crops, for example, crop productivity values of 7.6 to $14 \mathrm{~g} \mathrm{~mol}^{-1}, 4.6$ to $6.5 \mathrm{~g} \mathrm{~mol}^{-1}$, and 3.7 to $6.9 \mathrm{~g} \mathrm{~mol}^{-1}$ for cluster tomato, cherry tomato, and lettuce, respectively [28]. Specifically for strawberry fruit production, a 1.5 to $2.1 \mathrm{~g} \mathrm{~mol}^{-1}$ crop productivity was reported by [28]. The propagation efficacy to PPFD (daughter plants $\mathrm{mol}^{-1}$ ), in our experiment, was $0.36,0.30,0.29$ for 250-PPF, 350-PPF, and 450-PPF, respectively, for the 01 to 12 week cycle; and 1.94, 1.50, and 1.30 for 250-PPF, 350-PPF, and 450-PPF, respectively, for the 12 to 21 week cycle (Figure 5).

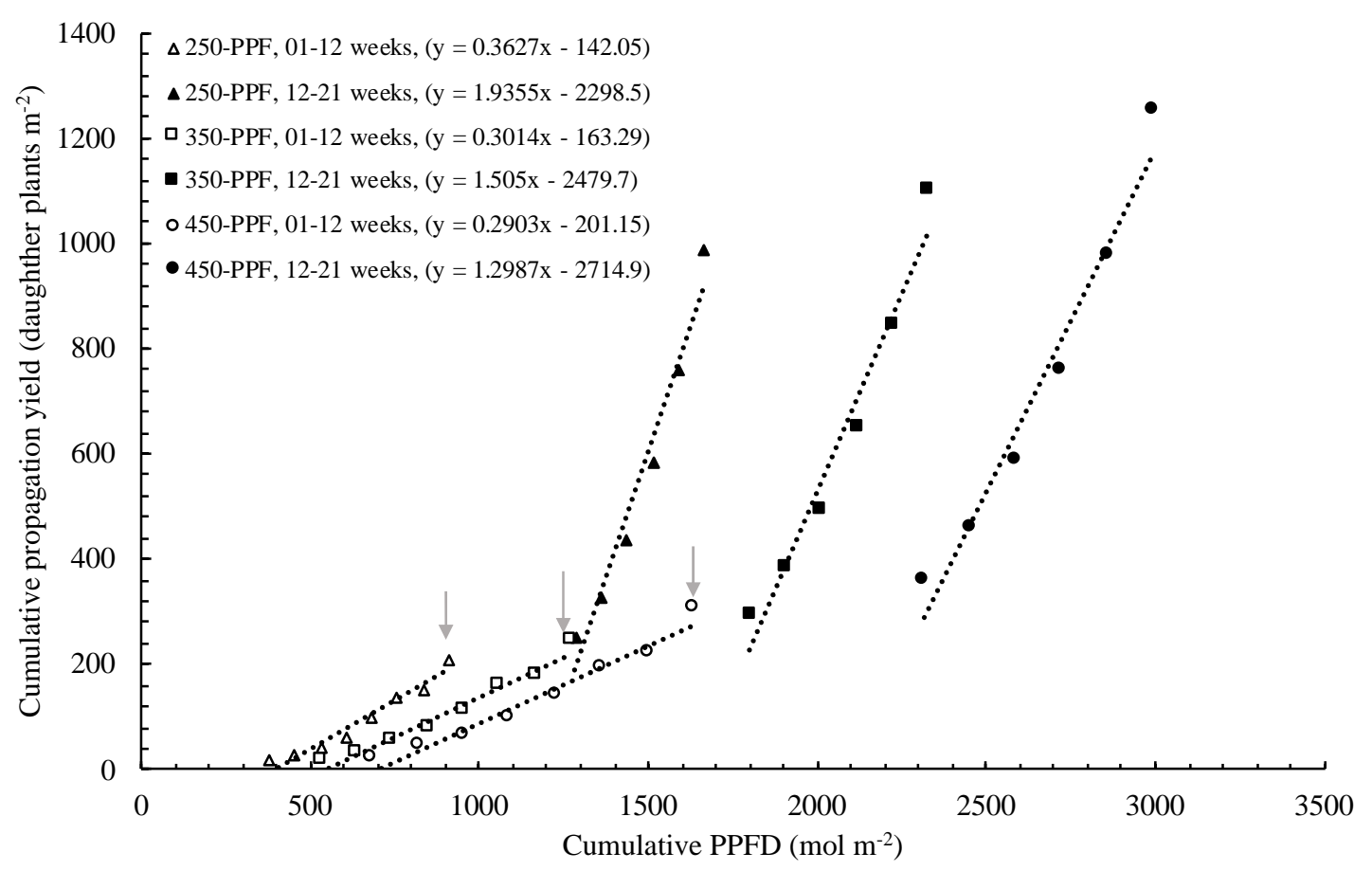

Figure 5. Propagation efficacy to photosynthetic photon flux density (PPFD) (daughter plants $\mathrm{mol}^{-1}$ ). Arrows represent the removal of all daughter plants after 12 weeks. Triangles, squares, and circles represent 250-PPF, 350-PPF, and 450-PPF light treatments, respectively. Open markers represent data collected for the 01 to 12 week cycle and filled markers represent data collected for the 12 to 21 week cycle. Solid line represents significant linear regression with $p \leq 0.05$.

Furthermore, the cost of electricity per daughter plant was estimated to be $\$ 0.029$ to $\$ 0.036$ for the 01 to 12 week cycle and $\$ 0.005$ to $\$ 0.008$ for the 12 to 21 week cycle. The cost for lighting often represents the largest production cost in PIP systems [38,39]; however, the cost estimated, in the present study, is relatively low on a per plant basis. It is important to understand the main assumptions made for the calculation, since they can significantly impact the results. For example, a plant density of 5.4 plants $\mathrm{m}^{-2}$ was used for the calculation (density used in this experiment). However, typical strawberry plant density in controlled environments can be up to 10 plants $\mathrm{m}^{-2}$ (using higher plant density could further decrease cost). It was also assumed that all daughter plants produced are able to root and become a usable transplant. However, daughter plants, in this experiment, range in size and also range in their capability to root (see result Section 3.2). The lamp electrical efficacy used for the calculation was based on high efficiency LEDs with a spectrum different than the one in this experiment. A different spectrum can change (increase or decrease) the propagation efficacy to PPFD 
(daughter plants $\mathrm{mol}^{-1}$ ). Nevertheless, more research is needed to further optimize and validate the use of PIP systems for the profitable production of strawberry daughter plants. These results offer the first available information on the potential cost of lighting for the propagation of strawberry plants in PIP systems.

The cumulative number of daughter plants over time during weeks 01 to 12 and 12 to 21 increased linearly per week for both cycles and all light intensities (Figure 6). In the 01 to 12 week cycle, plants grown in 450-PPF had a greater rate of 7.3 daughter plants per week per stock plant (plants wk ${ }^{-1}$ stock $^{-1}$ ) than plants in the 250-PPF and 350-PPF treatments which had a production rate of 5.1 to 5.9 plants $\mathrm{wk}^{-1}$ stock $^{-1}$. In the 12 to 21 week cycle, all treatments had a similar rate of daughter plant production of 6.7 to 7.9 plants $\mathrm{wk}^{-1}$ stock $^{-1}$ (Figure 6). On the basis of this experiment, the PIP propagation system produces an average rate of 6.7 plants $\mathrm{wk}^{-1}$ stock $^{-1}$ (average of all rates from Figure 6) which translates to 36.2 plants $\mathrm{wk}^{-1} \mathrm{~m}^{-2}$ (at 5.4 stock plant $\mathrm{m}^{-2}$ density). This number could be used to estimate the size of a facility to meet a particular demand on a specific season, for example, one-meter square would be able to produce 1881 daughter plants $\mathrm{yr}^{-1}$.

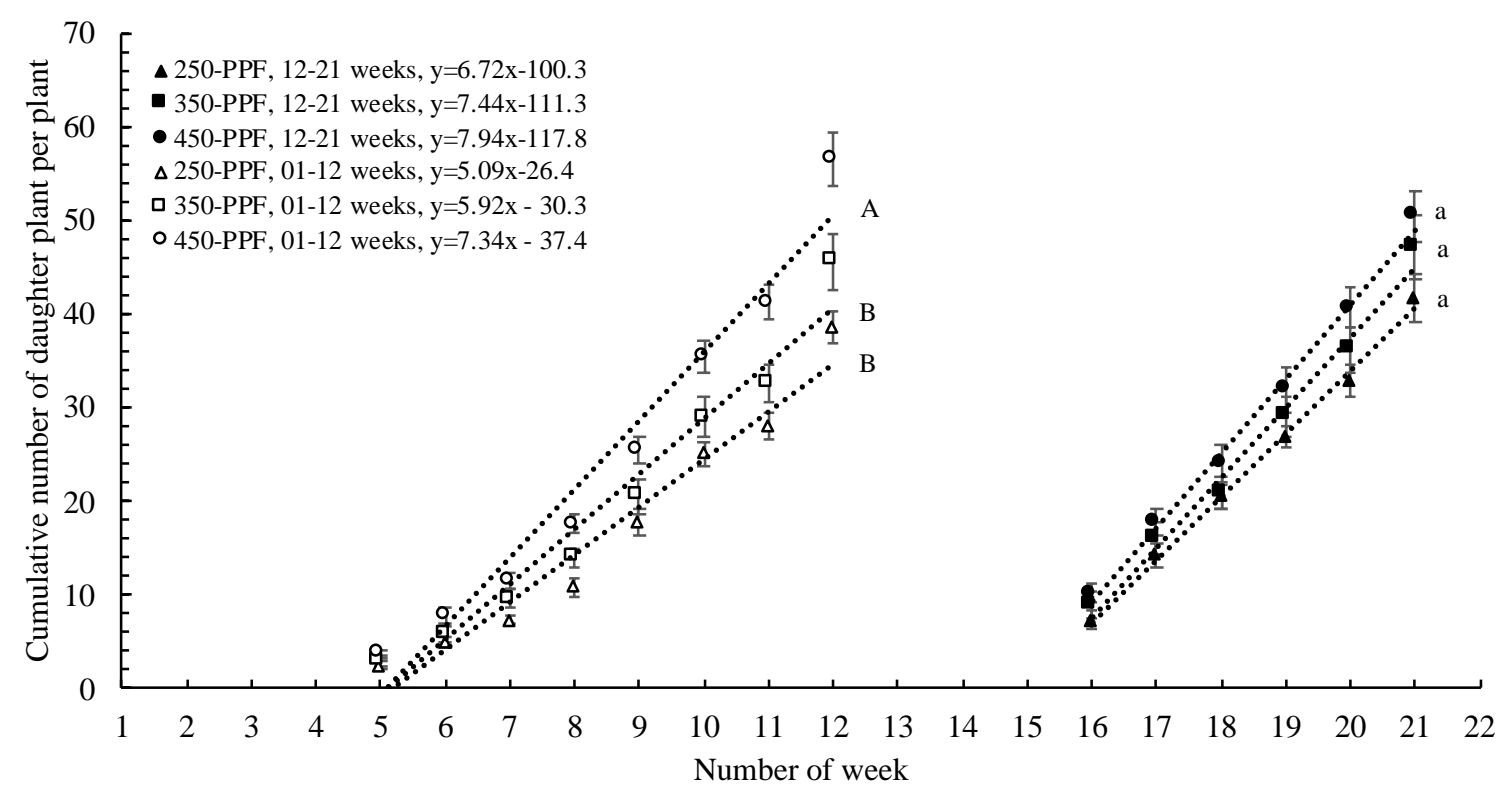

Figure 6. Cumulative number of daughter plants per stock plant per week of day neutral strawberry "Albion". Open symbols $(\Delta, \square, \bigcirc)$ represent data collected for the 01 to 12 week cycle, and closed symbols $(\boldsymbol{\Lambda}, \mathbf{\square}, \bullet)$ represent data collected for the 12 to 21 week cycle. Triangles $(\boldsymbol{\Delta}, \boldsymbol{\Delta})$, squares $\square)$, and circles $(\bullet, \bigcirc)$ represent plants grown under 250,350 , and $450 \mu \mathrm{mol} \mathrm{m}^{-2} \mathrm{~s}^{-1}$ light intensity, respectively. Dotted line represents significant linear regression $p \leq 0.05$. Letters $(A, B, C$, and $a, b)$ represent significant differences between slopes $p \leq 0.05$.

For the 01 to 12 week cycle, the total number of stolons per stock plant (3.2-3.7) was similar between light treatments (Figure 7). For the 12 to 21 week cycle, the stolon number per stock plant in 350-PPF (8.4) and 450-PPF (8.5) treatments was 38\% greater than in 250-PPF (6.1) (Figure 7). The total number of stolons per plant was 2.3 times greater in the 12 to 21 week cycle than that of the 01 to 12 week cycle. For both growing cycles, stock plants allocated more dry mass to the daughter plants than the stolons. However, the percent dry mass allocation to the stolon was greater in the 12 to 21 week cycle (Table 3). For both growing cycles, the number of daughter plants per stock plant was the same, but it was evident, for the 12 to 21 week cycle, that the plants increased stolon formation (branching) after the removal of all stolons during Week 12. Short-day strawberry "Maehyan" was propagated in an indoor system under different light intensities and the percent dry mass distribution of the daughter plants and stolon was not different between light intensity treatments [40]. However, 
in addition to having a different flowering physiology (short-day), the plants were only placed in treatments for 20 days (1.2 to 1.3 stolons per plant) and stolons were not removed from stock plants.

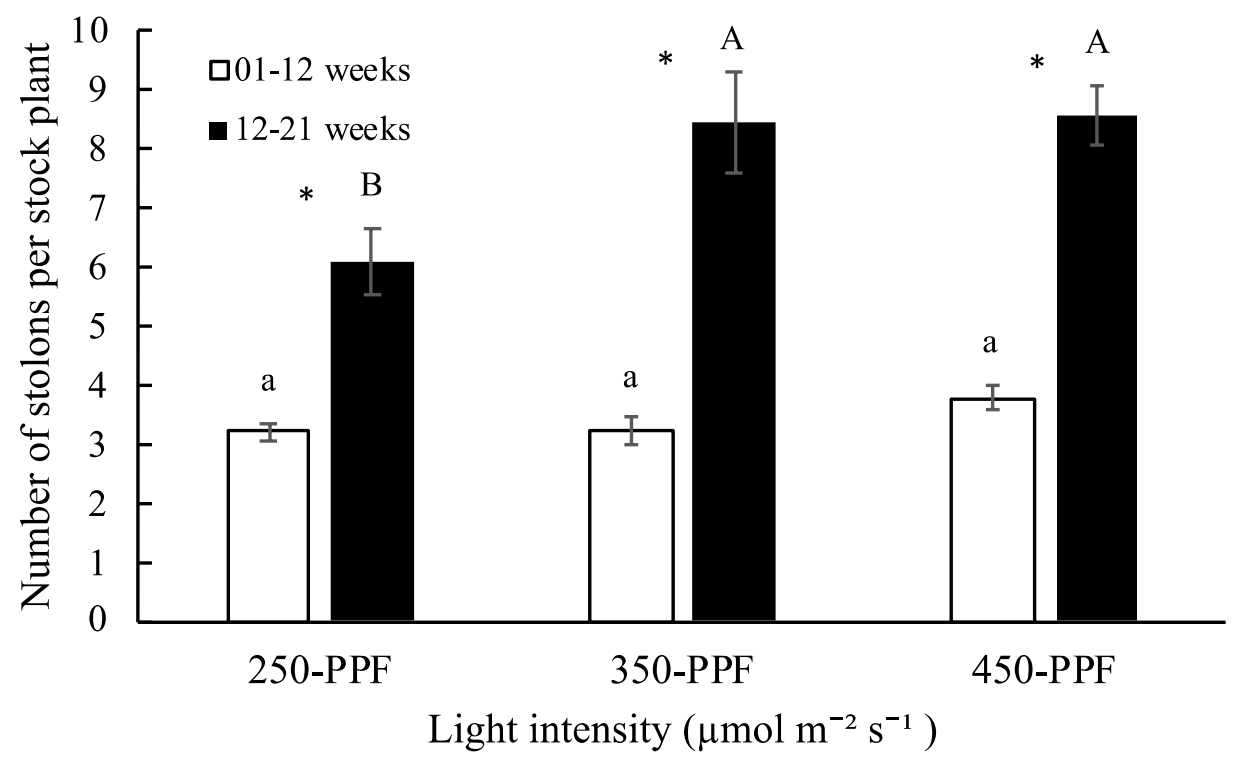

Figure 7. Effect of light intensity on stock plant stolon number of day neutral strawberry "Albion". * represents differences between the 01 to 12 week cycle and the 12 to 21 week cycle $(p \leq 0.05)$. Lowercase and uppercase letters represent differences between light treatments by growing cycle $(p \leq 0.05)$.

Table 3. Dry mass percent distribution of stolons and daughter plants for day neutral strawberry "Albion" grown under light treatments for 01 to 12 and 12 to 21 weeks. $p$-value represents differences between the two growing cycles $(p \leq 0.05)$.

\begin{tabular}{ccc}
\hline Plant Stage & Percent Daughter Plant Dry Mass & Percent Stolon Dry Mass \\
\hline $01-12$ weeks & $63.8 \pm 2.1 \%$ & $36.2 \pm 2.0 \%$ \\
$12-21$ weeks & $55.0 \pm 1.4 \%$ & $45.0 \pm 1.4 \%$ \\
$p$-value & $p<0.0001$ & $p<0.0001$ \\
\hline
\end{tabular}

\subsection{Daughter Plants Classification and Stolon Morphology}

The size classification of daughter plants was not influenced by light intensity in either growing cycle (Figure 8 ); around $60 \%$ to $66 \%$ of daughter plants were in the small and medium size classification and $20 \%$ to $26 \%$ were in premature bud classification.

The total number of daughter plants per stock plant per light treatment was the same between the two growing cycles (Figure 8) but the number of premature buds (PM in Figure 2) was higher in the 12 to 21 week cycle (Figure 8). The increase in premature buds from 12 to 21 weeks is associated with an increase of stolon number. Therefore, the total number of mature buds (XS, S, M, L, XL, in Figure 2) in 12 to 21 weeks would be greater than that in the 01 to 12 week cycle, if harvesting was extended for several more weeks. 


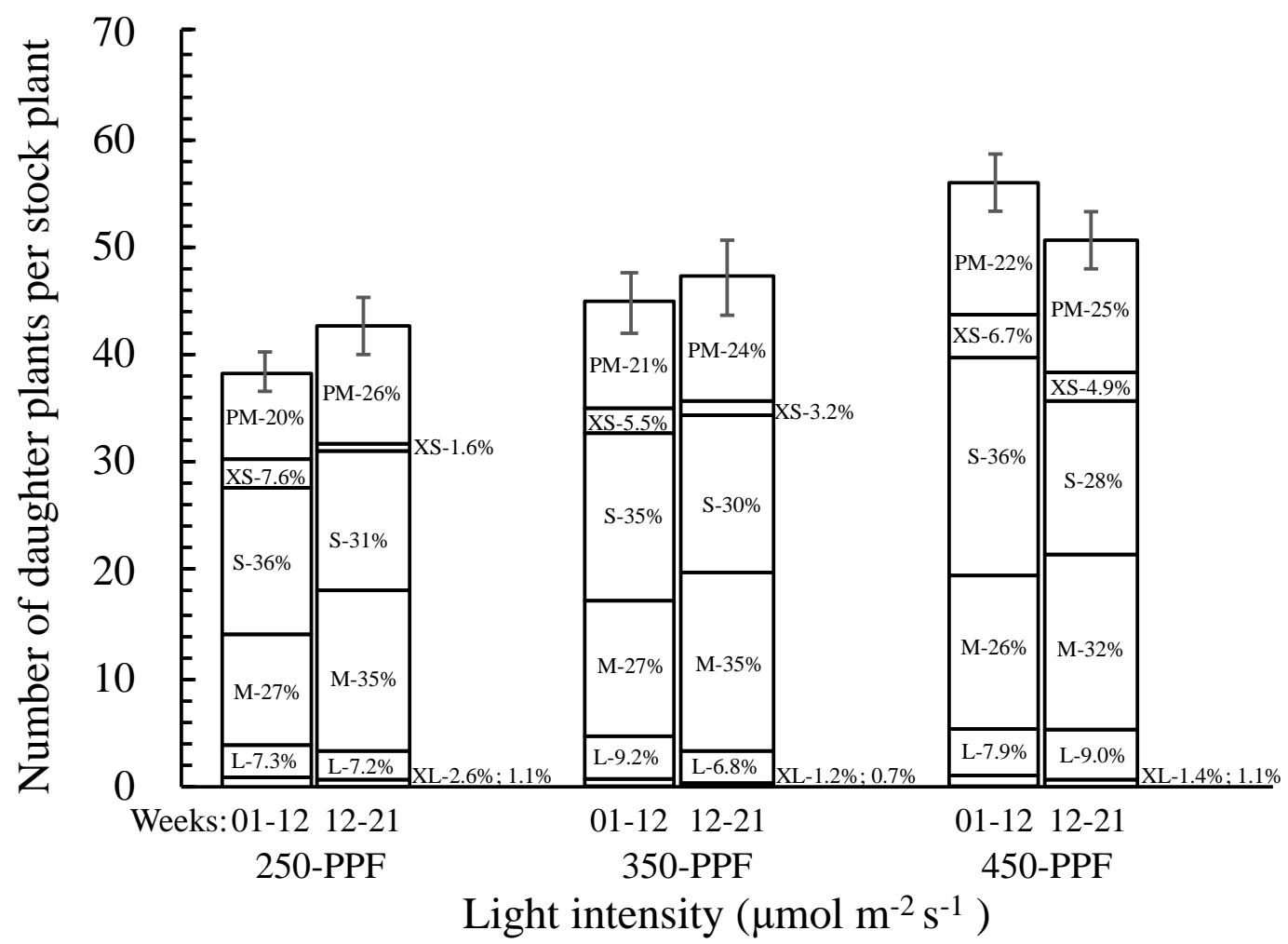

Figure 8. Total number of daughter plants per light intensity and growing cycle (01 to 12 weeks and 12 to 21 weeks). Each column is divided to represent the percent of daughter plants in each size category (crown size: $\mathrm{XL},>11 \mathrm{~mm}$; L, $8.5 \mathrm{~mm}$ to $11 \mathrm{~mm}$; M, $6 \mathrm{~mm}$ to $8.5 \mathrm{~mm}$;, $3.5 \mathrm{~mm}$ to $6 \mathrm{~mm}$; XS, <3.5 mm; and premature buds (PM).

\subsection{Relation between Flower Development and Stolon Generation}

The number of flowers removed decreased as the number of weeks increased in the 01 to 12 week cycle $(p<0.001)$ and after week 16 in the 12 to 21 week cycle $(p<0.001)$ (Figure 9). Generally, strawberry flowers take 35 days from initiation to visibility at the crown (Taylor et al., 1997). All the flowers removed at any given week were generally initiated five weeks earlier. Therefore, in the 01 to 12 week cycle, the flowers removed from Week 1 to Week 5 were initiated before the start of treatment (under much lower temperature). A distinct reduction of flower number was noticed in Week 7 and was associated with limited flower initiation in the environmental conditions driving stolon production.

Considering the 12 to 21 weeks cycle, after all the stolons were removed during Week 12, there was a clear increase in the number of flowers (weeks 13 to 16) (Figure 9). The flowers were formed approximately during Weeks 8 to 11, but the stolons from the 01 to 12 week cycle were serving as a stronger sink for available photoassimilates. Therefore, the dormant lateral buds were not growing to anthesis. After the stolons were removed on Week 12, the dormant lateral buds became the main sink organs and developed to anthesis. After new stolon formation (Week 16), stolons started competing for photoassimilates and, consequently, decreased the number of lateral buds reaching anthesis. When day-neutral strawberries are propagated in the field, the environmental conditions affect the development of flowers and often significant labor is used to remove developing flowers. As demonstrated in this experiment, the number of flowers can be greatly reduced by controlling environmental conditions using PIP. 


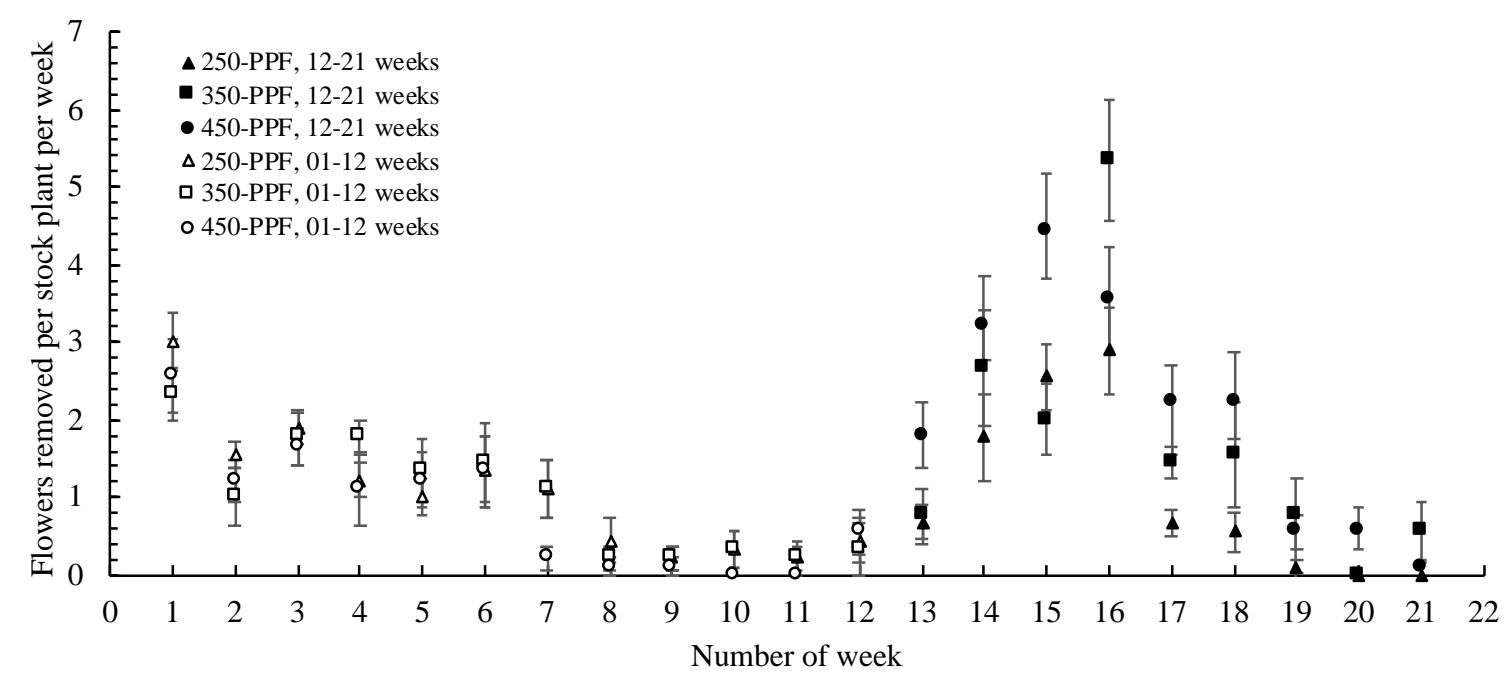

Figure 9. Flower removed per stock plant per week of day neutral strawberry "Albion". Open markers $(\Delta, \boldsymbol{\square}, \bigcirc)$ represent data collected for weeks 01 to 12 , and filled markers $(\boldsymbol{\Lambda}, \boldsymbol{\square}, \bullet)$ represent data collected for weeks 12 to 21 . Triangles $(\boldsymbol{\Delta}, \boldsymbol{\Delta})$, squares $(\boldsymbol{\square}, \mathbf{\square})$, and circles $(\bullet, \bigcirc)$ represent plants grown under 250,350 , and $450 \mu \mathrm{mol} \mathrm{m}^{-2} \mathrm{~s}^{-1}$ light intensity, respectively.

\subsection{Stock Plant Growth, Morphology, and Net Photosynthetic Rate}

Plant crown diameter (Figure 10a) and leaf count (Figure 10b) did not increase with an increase of light intensity in the 01 to 12 week cycle but did by the end of experiment ( 21 weeks). Plant leaf area, canopy fresh mass, and canopy dry mass measured at 21 weeks increased with an increase of light intensity (Figure 10c-e).

As expected, higher light intensity promoted stock plant growth, similar to other studies in strawberry. For example, Park et al. (2017) grew strawberry "Maehyang" (short-day) stock plant in different light intensity treatments and found that stock plants grown under $400 \mu \mathrm{mol} \mathrm{m} \mathrm{m}^{-2} \mathrm{~s}^{-1}$ (16 h photoperiod) had $40 \%$ and $85 \%$ greater dry mass than plants in $200 \mu \mathrm{mol} \mathrm{m}^{-2} \mathrm{~s}^{-1}$ and $100 \mu \mathrm{mol} \mathrm{m}^{-2} \mathrm{~s}^{-1}$, respectively.

Total shoot dry mass allocation was calculated by adding the dry mass of all harvested parts including daughter plants, stolons (without daughter plants), and stock plant (Table 4). The light intensity treatment did not affect the shoot dry mass distribution to the different organs. The percent dry mass allocated to the propagation portion (daughter plants and stolons) was over $85 \%$ (Table 4); however, only $45 \%$ to $46 \%$ was allocated to daughter plants (harvest index). Environmental conditions [41,42], cultivar [43], fruit load management [44], among others, can affect the dry mass partitioning between plant organs. For example, in tomatoes grown in greenhouses, the percent dry mass distribution to the tomato fruit is close to $60 \%$ to $70 \%$ [45,46]. Additional research is needed to increase the dry mass percent distribution to the daughter plants in PIP systems. 
Table 4. Shoot dry mass percent distribution of day neutral strawberry "Albion" at the end of the experiment (01 to 21 weeks). $p$-value represents differences between light treatments $(p \leq 0.05)$.

\begin{tabular}{cccc}
\hline Treatment & Percent Daughter Plant & Percent Stolon & Percent Stock Plant \\
\hline 250-PPF & $45.8 \pm 2.6 \%$ & $30.7 \pm 1.3 \%$ & $23.4 \pm 1.8 \%$ \\
350-PPF & $45.4 \pm 1.6 \%$ & $30.5 \pm 1.2 \%$ & $24.2 \pm 0.5 \%$ \\
$450-\mathrm{PPF}$ & $45.3 \pm 0.8 \%$ & $30.5 \pm 0.8 \%$ & $24.1 \pm 0.4 \%$ \\
$p$-value & $p=0.959$ & $p=0.9604$ & $p=0.7477$ \\
\hline
\end{tabular}
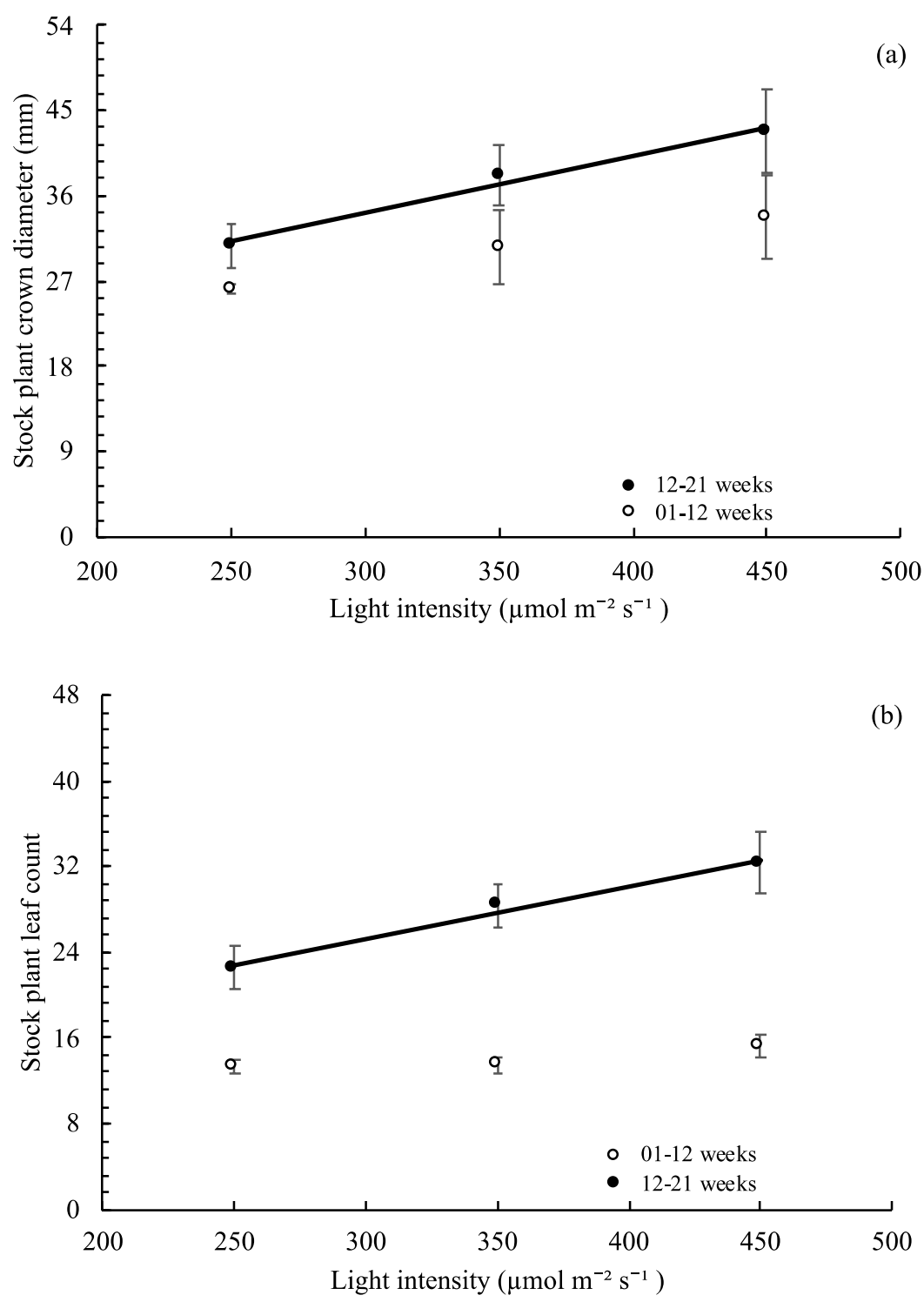

Figure 10. Cont. 

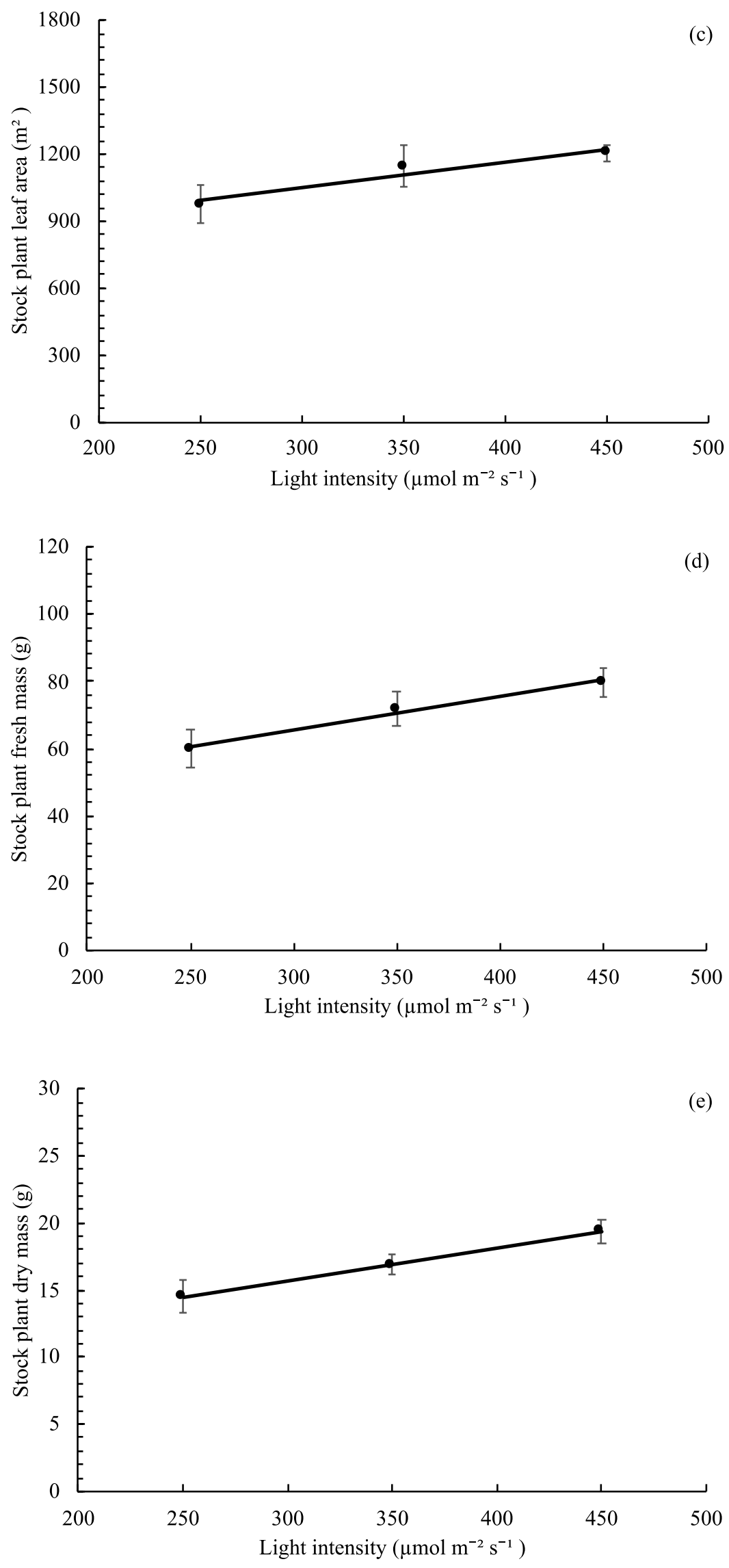

Figure 10. (a) Effect of light intensity on stock plant crown diameter; (b) leaf count; (c) leaf area; (d) fresh mass; and (e) dry mass, of day neutral strawberry "Albion". Open circles $(\bigcirc)$ represent data collected for the 01 to 12 week cycle and filled circles $(\bullet)$ represent data collected for the 12 to 21 week cycle. Solid line represents significant linear regression $(p \leq 0.05)$. 


\section{Conclusions}

An increase in light intensity increased the production of daughter plants per stock plant, for example, a 50\% increase between the lowest and highest light treatments was observed. However, the low light intensity treatment had higher propagation efficacy to light (daughter plants $\mathrm{mol}^{-1}$ ) than all other light treatments. Crown diameter size classification of daughter plants was no different between light treatments. Stock plant growth increased with an increase in light intensity and dry mass allocation between stock plant, daughter plant, and stolon was no different between the light treatments. Precision indoor propagation has the potential to increase the production yield of strawberry daughter plants. It is reasonable to use PIP systems to supplement open-field propagation.

Future studies should focus on optimizing other environmental conditions such as photoperiod, light quality, temperature, $\mathrm{CO}_{2}$, and nutrient dynamics.

Author Contributions: Conceptualization, R.H.; methodology, R.H. and X.X.; investigation, R.H. and X.X., writing-original draft preparation, X.X.; writing-review and editing, R.H. All authors have read and agreed to the published version of the manuscript.

Funding: This work was supported by the USDA National Institute of Food and Agriculture, the Hatch Improving Sustainability by Evaluating Novel Technologies and Techniques that Increase Energy Efficiency in Horticulture Production Systems project [1007454].

Acknowledgments: The authors would like to thank Cristian Collado for his technical support on the conceptualization and deployment of the growing system and Chieri Kubota for her critical review of the manuscript.

Conflicts of Interest: The authors declare no conflict of interest.

\section{References}

1. AGMRC. Strawberries. Available online: https://www.agmrc.org/commodities-products/fruits/strawberries (accessed on 12 December 2019).

2. Bolda, M.P.; Tourte, L.; Murdock, J.; Sumner, D.A. Sample Costs to Produce and Harvest Strawberries; University of California: Oakland, CA, USA, 2016.

3. Debode, J.; Van Hemelrijck, W.; Xu, X.M.; Maes, M.; Creemers, P.; Heungens, K. Latent entry and spread of Colletotrichum acutatum (species complex) in strawberry fields. Plant Pathol. 2015, 64, 385-395. [CrossRef]

4. Garcia, K.; Kubota, C. Flowering responses of North American strawberry cultivars. Acta Hortic. 2017, 1156, 483-490. [CrossRef]

5. Kubota, C.; The Ohio University, Columbus, OH, USA; Durner, E.F.; Rutgers University, New Brunswick, NJ, USA. Personal communication, 2019.

6. Mobini, S.H.; Lulsdorf, M.; Warkentin, T.D.; Vandenberg, A. Low red: Far-red light ratio causes faster in vitro flowering in lentil. Can. J. Plant Sci. 2016, 96, 908-918. [CrossRef]

7. Mishra, Y.; Johansson Jänkänpää, H.; Kiss, A.Z.; Funk, C.; Schröder, W.P.; Jansson, S. Arabidopsisplants grown in the field and climate chambers significantly differ in leaf morphology and photosystem components. BMC Plant Biol. 2012, 12, 6. [CrossRef] [PubMed]

8. Yokoi, S.; Goto, E.; Kozai, T.; Nishimura, M.; Taguchi, K.; Ishigami, Y. Effects of planting density and air current speed on the growth and uniformity of qing-geng-cai and spinach plug seedlings in a closed transplant production system. ECB 2008, 46, 103-114. [CrossRef]

9. Park, Y.; Runkle, E.S. Investigating the merit of including far-red radiation in the production of ornamental seedlings grown under sole-source lighting. Acta Hortic. 2016, 1134, 259-266. [CrossRef]

10. Wollaeger, H.M.; Runkle, E.S. Growth of Impatiens, Petunia, Salvia, and Tomato Seedlings under Blue, Green, and Red Light-emitting Diodes. Hortscience 2014, 49, 734-740. [CrossRef]

11. Hernández, R.; Eguchi, T.; Deveci, M.; Kubota, C. Tomato seedling physiological responses under different percentages of blue and red photon flux ratios using LEDs and cool white fluorescent lamps. Sci. Hortic. 2016, 213, 270-280. [CrossRef]

12. Sato, F.; Okada, K. Daily red LED illumination improves the quality of cabbage plug seedlings during low-temperature storage. J. Hortic. Sci. 2014, 89, 179-184. [CrossRef] 
13. Yao, X.-y.; Liu, X.-y.; Xu, Z.-g.; Jiao, X.-l. Effects of light intensity on leaf microstructure and growth of rape seedlings cultivated under a combination of red and blue LEDs. J. Integr. Agric. 2017, 16, 97-105. [CrossRef]

14. Hernández, R.; Kubota, C. Physiological responses of cucumber seedlings under different blue and red photon flux ratios using LEDs. Environ. Exp. Bot. 2016, 121, 66-74. [CrossRef]

15. Song, J.X.; Meng, Q.W.; Du, W.F.; He, D.X. Effects of light quality on growth and development of cucumber seedlings in controlled environment. Int. J. Agric. Biol. Eng. 2017, 10, 312-318.

16. Simlat, M.; Ślęzak, P.; Moś, M.; Warchoł, M.; Skrzypek, E.; Ptak, A. The effect of light quality on seed germination, seedling growth and selected biochemical properties of Stevia rebaudiana Bertoni. Sci. Hortic. 2016, 211, 295-304. [CrossRef]

17. Urairi, C.; Shimizu, H.; Nakashima, H.; Miyasaka, J.; Ohdoi, K. Optimization of light-dark cycles of lactuca sativa L. in plant factory. ECB. 2017, 55, 85-91. [CrossRef]

18. Kjaer, K.H.; Ottosen, C.-O.; Jørgensen, B.N. Cost-efficient light control for production of two campanula species. Sci. Hortic. 2011, 129, 825-831. [CrossRef]

19. Wu, C.C.; Hsu, S.T.; Chang, M.Y.; Fang, W. Effect of light environment on runner plant propagation of strawberry. Acta Hortic. 2011, 907, 297-302. [CrossRef]

20. Kim, S.; Jeong, M.-S.; Park, S.-W.; Kim, M.J.; Na, H.-Y.; Chun, C. Improvement of runner plant production by increasing photosynthetic photon flux during strawberry transplant propagation in a closed transplant production system. Korean J. Hortic. Sci. 2010, 28, 535-539.

21. Lopez, R.; Runkle, E. Light Management in Controlled Environments; Meister Media Worldwide: Willoughby, OH, USA, 2017.

22. Hidaka, K.; Dan, K.; Imamura, H.; Miyoshi, Y.; Takayama, T.; Sameshima, K.; Kitano, M.; Okimura, M. Effect of supplemental lighting from different light sources on growth and yield of strawberry. ECB 2013, 51, 41-47. [CrossRef]

23. Oda, Y. Effects of light intensity, $\mathrm{CO}_{2}$ concentration and leaf temperature on gas exchange of strawberry plants—feasibility studies on $\mathrm{CO}_{2}$ enrichment in japanese conditions. Acta Hortic. 1997, 439, 563-574. [CrossRef]

24. Sønsteby, A.; Heide, O.M. Dormancy relations and flowering of the strawberry cultivars Korona and Elsanta as influenced by photoperiod and temperature. Sci. Hortic. 2006, 110, 57-67. [CrossRef]

25. Sorkel, K.; Gaganpreet, S.; Kassim, A.-K. Strawberry (Fragaria Xananassa duch.) growth and productivity as affected by temperature. HortScience 2006, 41, 1423-1430. [CrossRef]

26. Verheul, M.J.; Sønsteby, A.; Grimstad, S.O. Influences of day and night temperatures on flowering of Fragaria $\mathrm{x}$ ananassa Duch, cvs. Korona and Elsanta, at different photoperiods. Sci. Hortic. 2007, 112, $200-206$. [CrossRef]

27. Heide, O.M. Photoperiod and temperature interactions in growth and flowering of strawberry. Physiol. Plant. 1977, 40, 21-26. [CrossRef]

28. Kubota, C.; Kroggel, M.; Both, A.J.; Whalen, M. Does supplemental lighting make sense for my crop?-Empirical evaluations. Acta Hortic. 2016, 1134. [CrossRef]

29. Acock, B.; Thornley, J.H.M.; Warren-Wilson, J. Photosynthesis and energy conversion. In Potential Crop Production; Wareing, P.F., Cooper, J.P., Eds.; Heinemann Educational Books: London, UK, 1971; pp. $43-75$.

30. Cockshull, K.E.; Graves, C.J.; Cave, C.R.J. The influence of shading on yield of glasshouse tomatoes. J. Hortic. Sci. 1992, 67, 11-24. [CrossRef]

31. Aldrich, R.A.; Bartock, J.W. Greenhouse Engineering; NRAES-Natural Resources, Agriculture, and Engineering Service: Ithaca, NY, USA, 1994; Volume 33.

32. Current-GE. Arize Element, Top Lighting. 2019. Available online: https://hortamericas.com/ wp-content/uploads/2018/05/GE2033-1128-GE-Arize-Element-Top-Lighting-Spec-Sheet.pdf (accessed on 10 October 2019).

33. Hernández, R.; Kubota, C. Physiological, morphological, and energy-use efficiency comparisons of LED and HPS supplemental lighting for cucumber transplant production. HortScience 2015, 50, 351-357. [CrossRef]

34. Lewis, M.; Kubota, C.; Tronstad, R.; Son, Y.-J. Scenario-based cost analysis for vegetable grafting nurseries of different technologies and sizes. HortScience 2014, 49, 917-930. [CrossRef]

35. Eric, B.B.; Daniel, J.C.; Craig, K.C. A system for producing large quantities of greenhouse-grown strawberry plantlets for plug production. HortTech 2001, 11, 636-638. [CrossRef] 
36. Takeda, F.; Hokanson, S.C. Strawberry fruit and plug plant production in the greenhouse. Acta Hortic. 2003, 626, 283-285. [CrossRef]

37. Marcelis, L.F.M.; Broekhuijsen, A.G.M.; Meinen, E.; Nijs, E.M.F.M.; Raaphorst, M.G.M. Quantification of the growth response to light quantity of greenhouse grown crops. Acta Hortic. 2006, 711, 97-104. [CrossRef]

38. Kozai, T.; Niu, G.; Takagaki, M. Plant Factory: An Indoor Vertical Farming System for Efficient Quality Food Production; Elsevier Science: Amsterdam, The Netherlands, 2019.

39. Ohyama, K.; Kozai, T.; Keita, Y. Electric energy, water and carbon dioxide utilization efficiencies of a closed-type trans plant production system. In Transplant Production in the 21st Century; Springer: Dordrecht, The Netherlands, 2000.

40. Park, S.; Kwack, Y.; Chun, C. Growth of runner plants grown in a plant factory as affected by light intensity and container volume. Hortic. Sci.Technol. 2017, 35, 439-445.

41. Lemoine, R.; La Camera, S.; Atanassova, R.; Dédaldéchamp, F.; Allario, T.; Pourtau, N.; Bonnemain, J.-L.; Laloi, M.; Coutos-Thévenot, P.; Maurousset, L.; et al. Source-to-sink transport of sugar and regulation by environmental factors. Front. Plant Sci. 2013, 4, 272. [CrossRef] [PubMed]

42. Heuvelink, E. Dry matter production in a tomato crop: Measurements and simulation. Ann. Bot. 1995, 75, 369-379. [CrossRef]

43. Li, T.; Heuvelink, E.; Marcelis, L.F.M. Quantifying the source-sink balance and carbohydrate content in three tomato cultivars. Front. Plant Sci. 2015, 6, 416. [PubMed]

44. Heuvelink, E. Effect of fruit load on dry matter partitioning in tomato. Sci. Hortic. 1997, 69, 51-59. [CrossRef]

45. Heuvelink, E. Dry matter partitioning in tomato: Validation of a dynamic simulation model. Ann. Bot. 1996, 77, 71-80. [CrossRef]

46. Heuvelink, E.; Buiskool, R.P.M. Influence of sink-source interaction on dry matter production in tomato. Ann. Bot. 1995, 75, 381-389. [CrossRef]

(C) 2020 by the authors. Licensee MDPI, Basel, Switzerland. This article is an open access article distributed under the terms and conditions of the Creative Commons Attribution (CC BY) license (http://creativecommons.org/licenses/by/4.0/). 